\title{
Genotypic and phenotypic characterization of Staphylococcus aureus causing persistent and nonpersistent subclinical bovine intramammary infections during lactation or the dry period
}

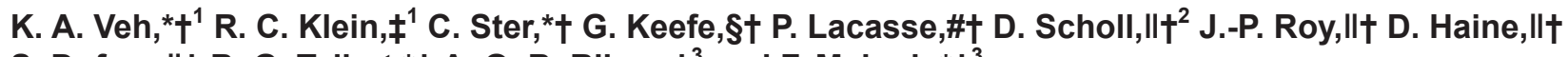 \\ S. Dufour,ll† B. G. Talbot, ${ }^{*} \dagger$ A. O. B. Ribon, $\ddagger^{3}$ and F. Malouin ${ }^{*} \dagger^{3}$ \\ ${ }^{*}$ Centre d'Étude et de Valorisation de la Diversité Microbienne (CEVDM), Département de Biologie, Faculté des Sciences, \\ Université de Sherbrooke, Sherbrooke, QC, Canada J1K 2R1 \\ †Canadian Bovine Mastitis and Milk Quality Research Network, C.P. 5000, St-Hyacinthe, QC, Canada J2S 7C6 \\ ‡Departmento de Bioquimica e Biologia Molecular, Universidade Federal de Viçosa, Viçosa 36570-000, MG, Brazil \\ §Centre for Veterinary Epidemiological Research, University of Prince Edward Island, Charlottetown, PE, Canada C1A 4P3 \\ \#Dairy and Swine Research and Development Centre, Agriculture and Agri-Food Canada, Sherbrooke, QC, Canada J1M 0C8 \\ IIDépartement de Pathologie et Microbiologie and Département de Sciences Cliniques, Faculté de Médecine Vétérinaire, Université de Montréal, \\ C.P. 5000, St-Hyacinthe, QC, Canada J2S 7 C6
}

\begin{abstract}
Staphylococcus aureus is a significant pathogen frequently causing persistent intramammary infections (IMI) in dairy cows. We compared some genotypic and phenotypic characteristics of 285 strains collected from quarter milk samples from cows with persistent and nonpersistent subclinical IMI across Canada. Variable number of tandem repeats typing was used to infer the persistence of the same $S$. aureus strain in 3 consecutive quarter milk samples collected at intervals of 3 wk during lactation or before and after dry-off. All first isolates of the series were used as the representative strains from persistent IMI and were compared with nonpersistent strains for the presence of genes seg, sen, sec, and tst as well as by spa typing. Biofilm production in vitro and $h l d$-RNAIII expression levels were also quantified. The gene seg was associated with a reduction in the likelihood of the bacteria to cause a persistent IMI during lactation. Strains persisting through the dry period produced significantly more biofilm in vitro than strains that do not persist after calving. Also, we showed that strains expressing more $h l d$ were more likely to be nonpersistent during either lactation or through the dry period. Three spa types were predominant (t529, t267, and a novel type: t13401). In the strains studied, the spa type t529 was the most frequent, and $97.0 \%$ of the strains of this spa type carried both sen and seg. Strains from the spa type t529 were less likely to cause a persistent IMI in the dry period. Most $(86.7 \%)$ of the strains
\end{abstract}

\footnotetext{
Received February 12, 2014.

Accepted September 24, 2014.

${ }^{1}$ These authors contributed equally to the work.

${ }^{2}$ Current address: South Dakota Agricultural Experiment Station.

${ }^{3}$ Corresponding authors: abribon@ufv.br and francois.malouin@ usherbrooke.ca
}

of the novel spa type (t13401) were negative for seg, sen, or both and produced significantly more biofilm in vitro than t529 and t267. The present study expanded our current knowledge on the genotypic and phenotypic traits of $S$. aureus strains recovered from persistent and nonpersistent IMI in Canada.

Key words: dairy cow, mastitis, Staphylococcus aureus, subclinical, persistence

\section{INTRODUCTION}

Staphylococcus aureus is an important etiological agent of clinical and subclinical bovine mastitis. A survey on dairy farms in Canada between 2007 and 2008 by the Canadian Bovine Mastitis Research Network (CBMRN) showed that $S$. aureus was the most frequently recovered pathogen from mastitis cases (Reyher et al., 2011). This also supported a previous study showing that $S$. aureus was the most prevalent pathogen causing mastitis in Canadian dairy herds (Olde Riekerink et al., 2008). Of particular interest are the $S$. aureus strains responsible for subclinical and persistent IMI. The presence of such strains represents a reservoir that maintains the occurrence of $S$. aureus infections in herds.

Staphylococcus aureus produces several virulence factors allowing establishment of IMI (Sutra and Poutrel, 1994). These factors can be divided into different groups, including surface-associated factors, degradative enzymes, hemolysins, staphylococcal enterotoxins (such as SEC, SEG, SEN, and others), and the toxic shock syndrome toxin-1 (TSST-1). The enterotoxins and TSST-1 affecting humans are known as superantigen toxins because of their ability to polyclonally activate T-cells in a nonspecific manner (Dinges et al., 2000). 
In humans, it is estimated that $80 \%$ of infections are associated with biofilm-producing bacteria (Davies, 2003). Biofilms reduce opsonization by antibodies and phagocytosis, and bacteria within biofilms are less susceptible to antibiotics (Costerton et al., 1999). In bovine, biofilm formation by $S$. aureus is also considered an important virulence factor, which may influence the persistence of IMI, but the in vivo demonstration of this still remains a challenge (Melchior et al., 2006). The in vitro biofilm-forming ability of $S$. aureus strains from IMI has been evaluated in different studies using a variety of methods (Oliveira et al., 2006; Dhanawade et al., 2010).

The regulatory circuits that control $S$. aureus virulence and adaptation to its environment are complex. These regulatory systems can receive signals from the external environment to modulate biofilm formation and the production of various exoproducts in a manner that is appropriate to the infection site (Novick, 2003; Ster et al., 2005). One of the regulatory systems, Agr, encodes a 2-component quorum-sensing constituent that is activated by bacterial density through secretion of an autoinducing peptide. The activation of Agr allows production of a regulatory RNA molecule, RNAIII, which is the effector molecule of the Agr system (Novick and Geisinger, 2008). The RNAIII allows reduction of surface proteins such as adhesins required for colonization. At the same time, RNAIII permits the production of secreted proteins such as nucleases and proteases, thus helping the release of bacteria from biofilms (Novick and Geisinger, 2008; Otto, 2013). Part of the RNAIII transcript is also translated to produce delta-hemolysin (Hld), which is one of the phenol-soluble modulins involved in structuring biofilm (Periasamy et al., 2012). Measurement of $h l d$-RNAIII expression levels can be used to estimate the level of activation of the Agr system in S. aureus (Novick, 2003).

The relative importance of the various virulence factors of $S$. aureus and the genetic background of the strains associated with bovine IMI have not been completely investigated. Studies around the world have reported a diversity of $S$. aureus genotypes associated with IMI (Akineden et al., 2001; Buzzola et al., 2001; Larsen et al., 2002; Zadoks et al., 2002; van Leeuwen et al., 2005; Haveri et al., 2008; Vautor et al., 2009; Wang et al., 2009; Hata et al., 2010; Wolf et al., 2011; Klein et al., 2012; Mitra et al., 2013). Also, S. aureus strains involved in bovine IMI were shown to present a variety of genotypes and phenotypes that include disease severity and IMI persistence and the capacity to produce specific toxins, biofilm, or both (Matsunaga et al., 1993; Fitzgerald et al., 2000; Cucarella et al., 2004; Zschöck et al., 2005; Zecconi et al., 2006; Haveri et al., 2007; Kalorey et al., 2007; Le Maréchal et al., 2011; Oliveira et al., 2011; Ote et al., 2011; Bardiau et al., 2014). Additional information is needed for a complete understanding of the disease and more specifically for identifying the bacterial factors responsible for the persistence of IMI. For example, it would be of interest to determine whether genotypic markers such as seg, sen, sec, tst, and the spa type as well as the phenotypic expression of biofilm and the level of $h l d$-RNAIII expression could be of prognostic value to predict the likelihood that a $S$. aureus subclinical IMI, either during lactation or at dry-off, would become persistent. Thus, the aim of this study was to systematically compare the characteristics of $S$. aureus strains recovered from documented subclinical persistent and nonpersistent IMI.

\section{MATERIALS AND METHODS}

\section{Bacterial Isolates Collection}

A total of 285 S. aureus strains from subclinical IMI were used in this study. Isolates were obtained from the CBMRN Mastitis Pathogen Culture Collection (Faculté de Médecine Vétérinaire, Université de Montréal, St-Hyacinthe, QC, Canada). As described in detail in Reyher et al. (2011), all isolates were collected from 29 herds in 2007 and 2008 and were obtained from 4 different areas of Canada (Atlantic Provinces, Quebec, Ontario, and Western Canada). Systematic sampling of quarter milk samples allowed lactational isolates to be collected from subclinical IMI. Milk samples from cows with clinical mastitis were thus excluded. If the different isolates recovered from 3 successive 3-weekly quarter milk samplings (S1, S2, S3) during the lactation period shared the same variable number of tandem repeats type (VNTR for 5 loci, as evaluated by multiplex PCR, see subsequent description), we considered that these isolates represented the same strain and that the IMI case was persistent. In such cases, only the isolate recovered from S1 was further characterized as the representative of the persistent strain (SUB-P, n $=139$ ). Those defined as nonpersistent strains (SUB$\mathbf{N P}, \mathrm{n}=38$ ) were present at the first sampling S1 but not at both S2 and S3. For both persistent and nonpersistent cases, at least one $S$. aureus colony from a $10-\mu \mathrm{L}$ milk sample needed to be found for the cases to be considered real infections (Dohoo et al., 2011). Also, on average, the reported SCC for the S1 samples taken during lactation were $1,447,000$ and 889,800 for persistent and nonpersistent cases, respectively. More details on sampling procedures, herd and cow characteristics, and the CBMRN isolates collection is provided in Reyher et al. (2011). 
For the dry period, isolates were retrieved from milk of subclinical IMI before dry-off and after calving. Blanket antibiotic therapy was used on all dry cows. If the different isolates retrieved before and after dryoff shared the same VNTR type, we considered that these isolates represented the same strain and that the IMI case was persistent. In such cases, only the isolate recovered before dry-off was further characterized as the representative of the persistent strain (DC-P, n $=44)$. Those defined as nonpersistent strains were not reisolated at calving and did not survive the antibiotic blanket therapy applied to all dry cows (DC-NP, n = 64). As for the lactation series, at least one $S$. aureus colony from a $10-\mu \mathrm{L}$ milk sample needed to be found for the cases to be considered real infections. Also, on average, the reported SCC for the samples taken before dry-off were 2,642,900 and 1,487,300 for persistent and nonpersistent cases, respectively. Finally, S. aureus strain Newbould (ATCC 29740) was used as the reference strain for comparison to our strain collection, and strain N315 was used as a positive control for the detection of the enterotoxin genes.

Staphylococcus aureus from the Mastitis Pathogen Culture Collection were identified from milk as grampositive cocci showing a positive catalase test, hemolysis on blood agar, and positive nuclease and coagulase tests (Reyher et al., 2011). For this study, strains from the Mastitis Pathogen Culture Collection frozen stocks were streak on mannitol salt agar to provide an additional confirmation of identification before further strain characterization.

\section{Preparation of Genomic DNA}

Staphylococcus aureus isolates were grown overnight at $35^{\circ} \mathrm{C}$ in brain heart infusion $(\mathbf{B H I})$ broth $(\mathrm{BD}, \mathrm{ON}$, Canada). The recommendations from the manufacturers of the Gene Elute kit (Sigma Aldrich Canada, Oakville, ON, Canada) were followed for gDNA extraction. The exception was the use of lysis buffer composed of $1 \mathrm{X}$ TE buffer, lysozyme $(45 \mu \mathrm{g} / \mathrm{mL})$, and lysostaphin $(200 \mu \mathrm{g} /$ $\mathrm{mL}$ ) to achieve efficient lysis of $S$. aureus cells. Extracted genomic DNA (gDNA) was stored at $-20^{\circ} \mathrm{C}$ until use.

\section{Evaluation of Persistence by VNTR Typing}

The VNTR loci typing was described previously by Sabat et al. (2003). Variable number of tandem repeats was used to detect $S$. aureus strains from persistent IMI. A strain was considered persistent if lactational $\mathrm{S} 1, \mathrm{~S} 2$, and $\mathrm{S} 3$ isolates or the before and after dry-off isolates had an identical VNTR profile. Briefly, VNTR is based on analysis of 5 tandem repeat loci. Repetitive DNA from the V8 serine protease (ssp), protein A ( spa),
Ser-Asp-rich fibrinogen-binding protein $(s d r C D E)$, clumping factor B ( clfB), and clumping factor A (clfA) genes were amplified in a single multiplex PCR. Amplified products were separated by electrophoresis on $2 \%$ agarose gel, stained with ethidium bromide, and then visualized by UV transilluminator and photographed. The sequences of primers for VNTR are listed in Table 1. As mentioned above, only the first isolate of the series (S1 or the before dry-off isolates) was used as the representative of the persistent strain for detailed characterization and comparison to the nonpersistent strains.

\section{Detection of Genes by PCR}

All of the selected persistent and nonpersistent $S$. aureus strains $(\mathrm{n}=285)$ were used to perform PCR analysis to detect the superantigen genes seg, sen, sec, tst as well as the positive control gene femA. The femA gene encodes a cell-wall biosynthesis gene that is universally present in all $S$. aureus isolates (Mehrotra et al., 2000). Oligonucleotide primers (Table 1) were synthesized by Sigma Aldrich Canada. One multiplex PCR (genes sec, tst, and femA) and 2 simplex PCR (sen and seg) were performed for the detection of toxin genes. The PCR reactions were performed in a final volume of $25 \mu \mathrm{L}$ of reaction mixture consisting of $2.5 \mu \mathrm{L}$ of $10 \mathrm{X}$ PCR buffer (NEB, Ipswich, MA), 0.2 or $0.4 \mu M$ of each primer, $0.4 \mathrm{~m} M$ of dNTP each, $3 \mathrm{mM}$ of $\mathrm{MgCl}_{2}$ (NEB), $0.1 \mathrm{U}$ of Taq DNA polymerase (NEB), and $300 \mathrm{ng}$ of template DNA. All PCR reactions were performed using a GeneAmp PCR system 2700 (Life Technologies, Burlington, ON). The cycling conditions were the following: an initial denaturation at $95^{\circ} \mathrm{C}$ for $4 \mathrm{~min}$; 35 cycles of $95^{\circ} \mathrm{C}$ for $30 \mathrm{~s}$; a specific temperature for $30 \mathrm{~s}$ (Table 1 ); $68^{\circ} \mathrm{C}$ for $30 \mathrm{~s}$; and a final extension at $68^{\circ} \mathrm{C}$ for 10 min. The gDNA of strain $S$. aureus N315 was used as a positive control because this strain possesses all the toxin genes. A negative control without gDNA was also included in each series of PCR amplifications. Amplified products were resolved by electrophoresis on $1.5 \%$ agarose gel, stained with ethidium bromide (0.5 $\mu \mathrm{g} / \mathrm{mL}$ ), and visualized by a UV transilluminator.

\section{Biofilm Production In Vitro}

Isolates were grown on BHI agar supplemented with $0.25 \%$ glucose and incubated at $35^{\circ} \mathrm{C}$ for 18 to $24 \mathrm{~h}$. The culture was used to prepare a bacterial suspension in BHI $0.25 \%$ glucose broth (0.5 McFarland standard). A $50-\mu \mathrm{L}$ volume of the bacterial suspension was added to each well of a flat-bottom polystyrene microtiter plate containing a half volume of the same medium as previously described (Mitchell et al., 2010). The plates were 
Table 1. Target genes, primer sequences, expected sizes of amplicons, and PCR conditions

\begin{tabular}{|c|c|c|c|c|}
\hline Gene & Primer sequence $^{1}$ & $\begin{array}{l}\text { Product } \\
\text { size (bp) }\end{array}$ & $\begin{array}{c}\text { PCR } \\
\text { (hybridization } \\
\text { temperature, }{ }^{\circ} \mathrm{C} \text { ) }\end{array}$ & Reference \\
\hline $\operatorname{seg}$ & $\begin{array}{l}\text { Fwd: AATTATGTGAATGCTCAACCCGATC } \\
\text { Rev: AAACTTATATTGGAACAAAAGGTACTAGTTC }\end{array}$ & 642 & 50 & Jarraud et al., 2002 \\
\hline $\sec$ & $\begin{array}{l}\text { Fwd: GTAAAGTTACAGGTGGCAAAACTTG } \\
\text { Rev: CATATCATACCAAAAAGTATTGCCGT }\end{array}$ & 297 & 50 & Jarraud et al., 2002 \\
\hline tst & $\begin{array}{l}\text { Fwd: TTCACTATTTGTAAAAGTGTCAGACCCACT } \\
\text { Rev: TACTAATGAATTTTTTTATCGTAAGCCCTT }\end{array}$ & 180 & 50 & Jarraud et al., 2002 \\
\hline $\operatorname{sen}$ & $\begin{array}{l}\text { Fwd: ATTGTTCTACATAGCTGCAA } \\
\text { Rev: TTGAAAAAACTCTGCTCCCA }\end{array}$ & 681 & 50 & Jarraud et al., 2002 \\
\hline femA & $\begin{array}{l}\text { Fwd: ACAGCTAAAGAGTTTGGTGCCTIIIIGATAGCATGC } \\
\text { Rev: TTCATCAAAGTTGATATACGCTAAAGGTIIIICACACGGTC }\end{array}$ & 729 & 50 & This study \\
\hline hld & $\begin{array}{l}\text { Fwd: TAATTAAGGAAGGAGTGATTTCAATG } \\
\text { Rev: TTTTTAGTGAATTTGTTCACTGTGTC }\end{array}$ & 100 & 60 & Mitchell et al., 2008 \\
\hline $\operatorname{gyr} B$ & $\begin{array}{l}\text { Fwd: GGTGCTGGGCAAATACAAGT } \\
\text { Rev: TCCCACACTAAATGGTGCAA }\end{array}$ & 107 & 60 & Moisan et al., 2006 \\
\hline $\operatorname{ssp} A$ & $\begin{array}{l}\text { Fwd: ATCMATTTYGCMAAYGATGACCA } \\
\text { Rev: TTGTCTGAATTATTGTTATCGCC }\end{array}$ & 132 & 55 & Sabat et al., 2003 \\
\hline spa & $\begin{array}{l}\text { Fwd: AGCACCAAAAGAGGAAGACAA } \\
\text { Rev: GTTTAACGACATGTACTCCGT }\end{array}$ & 290 & 55 & Sabat et al., 2003 \\
\hline clfA & $\begin{array}{l}\text { Fwd: GATTCTGACCCAGGTTCAGA } \\
\text { Rev: CTGTATCTGGTAATGGTTCTTT }\end{array}$ & 945 & 55 & Sabat et al., 2003 \\
\hline clfB & $\begin{array}{l}\text { Fwd: ATGGTGATTCAGCAGTAAATCC } \\
\text { Rev: CATTATTTGGTGGTGTAACTCTT }\end{array}$ & 880 & 55 & Sabat et al., 2003 \\
\hline$s d r C D E$ & $\begin{array}{l}\text { Fwd: GTAACAATTACGGATCATGATG } \\
\text { Rev: TACCTGTTTCTGGTAATGCTTT }\end{array}$ & $648 / 580 / 622$ & 55 & Sabat et al., 2003 \\
\hline spa typing & $\begin{array}{l}\text { spa-113f: TAAAGACGATCCTTCGGTGAGC } \\
\text { spa-1514r: CAGCAGTAGTGCCGTTTGCTT }\end{array}$ & 110 to 422 & 63 & Aires-de-Sousa et al., 2006 \\
\hline
\end{tabular}

\footnotetext{
${ }^{1} \mathrm{Fwd}=$ forward; Rev $=$ reverse
} 
incubated at $35^{\circ} \mathrm{C}$ for $24 \mathrm{~h}$. After incubation, the wells were washed 3 times with PBS, air dried, and stained with a $0.1 \%$ crystal violet solution for $30 \mathrm{~min}$. The plates were washed, and the adherent biofilm was then dissolved in ethanol. The absorbance was measured at $560 \mathrm{~nm}$ by spectrophotometry (Bio-Tek Instruments, Winooski, VT) and normalized according to the biofilm production measured for the reference $S$. aureus strain Newbould (ATCC 29740). Biofilm production by each strain was determined from 3 independent experiments performed on 3 different days. Each independent experiment included 4 wells for each strain (4 technical replicates).

\section{Quantitative Expression of hld (qPCR)}

Bacterial cultures grown overnight were used to inoculate BHI broth to an optical density of 0.1 at 600 $\mathrm{nm}$. The bacteria were then grown at $35^{\circ} \mathrm{C}$ until they reached 0.4 optical density and treated with RNAprotect (Qiagen, Mississauga, ON). The RNA was extracted from the pellets after bacterial lysis with lysostaphin $(200 \mu \mathrm{g} / \mathrm{mL})$ for $1 \mathrm{~h}$ at $35^{\circ} \mathrm{C}$ using the RNeasy Mini kit and the RNase-free DNase set (Qiagen). One microgram of total RNA was reverse transcribed with 0.5 $\mathrm{m} M$ of dNTP, $50 \mathrm{ng}$ of random hexamers, and $200 \mathrm{U}$ of Invitrogen Superscript II reverse transcriptase according to the manufacturer's recommendations (Life Technologies). The RNA was hydrolyzed and the cDNAs were purified with the QIAquick PCR purification kit (Qiagen). One microliter of the cDNA preparation was amplified on the Stratagene MX3000P Real-Time PCR instrument with the Jump Start Taq DNA polymerase (Sigma Aldrich Canada), SYBR Green, and $10 \mu M$ of the primers (Table 1). Reaction mixtures were denatured for $10 \mathrm{~min}$ at $95^{\circ} \mathrm{C}$, followed by 35 cycles of $30 \mathrm{~s}$ at $95^{\circ} \mathrm{C}, 1 \mathrm{~min}$ at $60^{\circ} \mathrm{C}$, and $1 \mathrm{~min} 30 \mathrm{~s}$ at $72^{\circ} \mathrm{C}$. Dissociation and standard curves were obtained to ensure the specificity and the efficiency of reactions. Relative expression was calculated by using the cycle threshold (Ct) of $\operatorname{gyr} B$ as the calibrator gene for each isolate. The RNAIII ( $h l d$ gene) expression $(\Delta \mathrm{Ct}$ ) was calculated by using the difference between the $(\mathrm{Ct})$ of RNAIII and $(\mathrm{Ct})$ of $\operatorname{gyr} B$ for each isolate. We used gyrB as a calibrator because gyr $B$ expression did not vary significantly in the exponential growth phase. The fold expression of the hld gene from each experiment was then normalized with the general value of Newbould $(\Delta \mathrm{Ct})$ expression (fold expression $=2^{-\Delta \Delta \mathrm{Ct}}$ ).

\section{spa Typing}

The polymorphic $\mathrm{X}$ region of the protein $\mathrm{A}$ gene (spa) was amplified using the primers spa-1113f and spa-1514r (Table 1), as described by Aires de Sousa et al. (2006). The PCR was performed in a total volume of $20 \mu \mathrm{L}$ containing $100 \mathrm{ng}$ of DNA, $0.2 \mathrm{mM}$ of each dNTP (dATP, dCTP, dGTP, and dTTP), 10 pmol of each primer, $2 \mu \mathrm{L}$ of $10 \times$ PCR Buffer II (Life Technologies), $1.5 \mathrm{mM}$ of $\mathrm{MgCl}_{2}$, and $1.25 \mathrm{U}$ of Ampli Taq DNA polymerase (Life Technologies). Thermal cycling reactions consisted of an initial denaturation at $95^{\circ} \mathrm{C}$ for $5 \mathrm{~min}$, followed by 30 cycles of denaturation at $95^{\circ} \mathrm{C}$ for $30 \mathrm{~s}$, annealing at $63^{\circ} \mathrm{C}$ for $30 \mathrm{~s}$, and extension at $72^{\circ} \mathrm{C}$ for 45 $\mathrm{s}$, with a single 7-min final extension. Five microliters of the PCR reaction were used to check the amplicons on a $0.8 \%$ agarose gel. Another $2.5-\mu \mathrm{L}$ volume of the PCR reaction was diluted with the same volume of nanopure water and sent for sequencing at the Plate-forme d'Analyses Biomoléculaires de l'Université Laval (Université Laval, QC, Canada). Samples were sequenced using the same primers described before. The ab1 files from sequencing were submitted to BioNumerics software v5.1 (Applied Maths, Austin, TX), and using the spa typing plug-in, all spa sequences were compared against the spa database server (http://www.spaserver. ridom.de/). One specific spa type was assigned to each isolate.

\section{Statistical Analysis}

Logistic regression models were developed to associate genotypic markers (sen, sec, seg, and tst), biofilm production, and hld expression to persistence of strains during lactation and over the dry period. Logistic regression models were also used to associate the major spa types (t267, t529, and t13401) to persistence of strains during lactation and over the dry period. The models included province of sampling as a fixed effect covariate and herd as a random effect. To assess any province effect, pairwise differences between provinces were realized with Tukey's multiple comparisons test. Biofilm production and hld expression according to the different $S$. aureus strains were analyzed with a linear mixed model including herd as a random effect and province as a fixed effect. The dependent variable was log-transformed in these models because of their skewed distribution. Pairwise differences between strains were realized with Tukey's multiple comparisons test. Biofilm and hld were also analyzed in the same manner according to spa type. Genetic diversity within each strain groups (SUB-P, SUB-NP, DC-P, DC-NP) was determined with Simpson's index (Simpson, 1949), and their confidence intervals were constructed by boostrap method (Dixon, 1993; Efron and Tibshirani, 1997; Mills and Zandvakili, 1997). Bootstrap analysis of the difference between each diversity indices was computed using 2,000 boostrap 
resamples. All statistics were realized with $\mathrm{R}$ version 3.1.1 (R Core Team, 2012).

\section{RESULTS}

\section{Evaluation of Persistence by VNTR Typing}

In this study, $S$. aureus strains were considered as "persistent" if all 3 isolates from all successive samplings during lactation (S1, S2, and $\mathrm{S} 3$ at 0,3 , and 6 wk, respectively) showed the same VNTR profile on agarose gel. Among a collection of 153 putative persistent IMI cases (3 isolates per case), 139 cases were considered as true persistent by VNTR typing (91\% of the original set of cases showing presence of $S$. aureus in S1, S2, and S3 samples). The false-persistent cases were excluded from the study, and the 139 isolates from S1 were considered the representatives of the persistent strains (SUB-P) and were retained for the study. These 139 persistent strains were compared with 38 nonpersistent strains, i.e., cases where $S$. aureus was only present in S1 (SUB-NP).

From an initial collection of 53 cases of IMI lasting over the dry period (i.e., $S$. aureus present before and after the dry period), 44 (83\%) cases were considered true-persistent IMI based on VNTR typing. The falsepersistent cases were excluded from the study, and the 44 isolates taken before dry-off were considered the representatives of the persistent strains (DC-P). These 44 strains were retained for the study and were compared with 64 nonpersistent strains (DC-NP) only found before dry-off.

The number of representative strains did not differ among the 4 different groups studied (DC-P, DC-NP, SUB-P, SUB-NP) across the 4 geographic regions, i.e., no region existed where one group was over- or underrepresented $(P=0.211)$. Statistical analysis revealed that SUB-P strains were isolated more frequently in cows that had more DIM during the lactation period $(P<0.001)$.

\section{Detection of Genotypic Markers}

The distribution of the 4 superantigen-encoding genes investigated among the different groups of strains (SUB-P, SUB-NP, DC-P, DC-NP) is reported in Table 2. Statistical analysis (logistic regression, adjusted for province of sampling as well as for clustering between herds) for strains recovered during lactation revealed that the presence of the gene seg is associated with a reduction in the possibility that the bacteria persist by $66 \%$ [odds ratio $(\mathbf{O R})=0.34,95 \%$ CI: $0.14-0.85, P=$ 0.021]. This suggests that the presence of seg may be associated with the nonpersistent strains found in subclinical IMI during lactation. Similarly, and also again for strains collected during lactation, the presence of both seg and sen in the same strain is associated with a reduction in the possibility that the bacteria persist by $69 \%(\mathrm{OR}=0.31,95 \% \mathrm{CI}: 0.13-0.72, P=0.007)$. No other statistically significant regression was found for the data presented in Table 2.

\section{Biofilm Production In Vitro}

The ability to form biofilm was investigated for each strain group (Figure 1). Data show that DC-P strains produced significantly more biofilm in vitro than strains that do not persist after calving (DC-NP; $P=0.008$, Figure 1). However, according to the logistic regression, we do not see any change in the odds of being persistent for a one-unit increase in biofilm production for the lactation or the dry period $(\mathrm{OR}=1.33,95 \%$ CI: $0.72-2.47, P=0.367$; and $\mathrm{OR}=1.44,95 \% \mathrm{CI}$ : $0.92-2.27, P=0.111$, respectively, for the lactation or dry period).

\section{hld Expression}

The expression level of hld was also compared among the different groups of strains (Figure 2). No statistical differences were found between SUB-P and SUB-NP or

Table 2. Distribution (\%) of target genes among all the 285 Staphylococcus aureus strains studied ${ }^{1}$

\begin{tabular}{lccccc}
\hline & \multicolumn{2}{c}{ Lactation period $(\mathrm{n}=177)$} & & \multicolumn{2}{c}{ Dry period $(\mathrm{n}=108)$} \\
\cline { 2 - 3 } \cline { 5 - 6 } Gene & $\begin{array}{c}\text { SUB-P } \\
(\mathrm{n}=139)\end{array}$ & $\begin{array}{c}\text { SUB-NP } \\
(\mathrm{n}=38)\end{array}$ & & $\begin{array}{c}\text { DC-P } \\
(\mathrm{n}=44)\end{array}$ & $\begin{array}{c}\text { DC-NP } \\
(\mathrm{n}=64)\end{array}$ \\
\hline sec+ & 5.0 & 10.5 & & 9.1 & 6.2 \\
tst & 8.6 & 15.8 & & 15.9 & 9.4 \\
seg+ & 49.6 & 68.4 & & 34.1 & 46.9 \\
sen+ & 51.8 & 68.4 & & 45.5 & 60.9 \\
sen+ and seg+ & 41.0 & 65.8 & & 34.1 & 46.9 \\
sen-, seg-, or both & 59.0 & 34.2 & & 65.9 & 53.1 \\
\hline
\end{tabular}

${ }^{1}$ SUB-P $=$ persistent strains from subclinical IMI during lactation; SUB-NP = nonpersistent strains from subclinical IMI during lactation; DC-P = strains from subclinical IMI persisting through the dry period; DC-NP $=$ strains from subclinical IMI not persisting through the dry period (i.e., not found in fresh cows). 


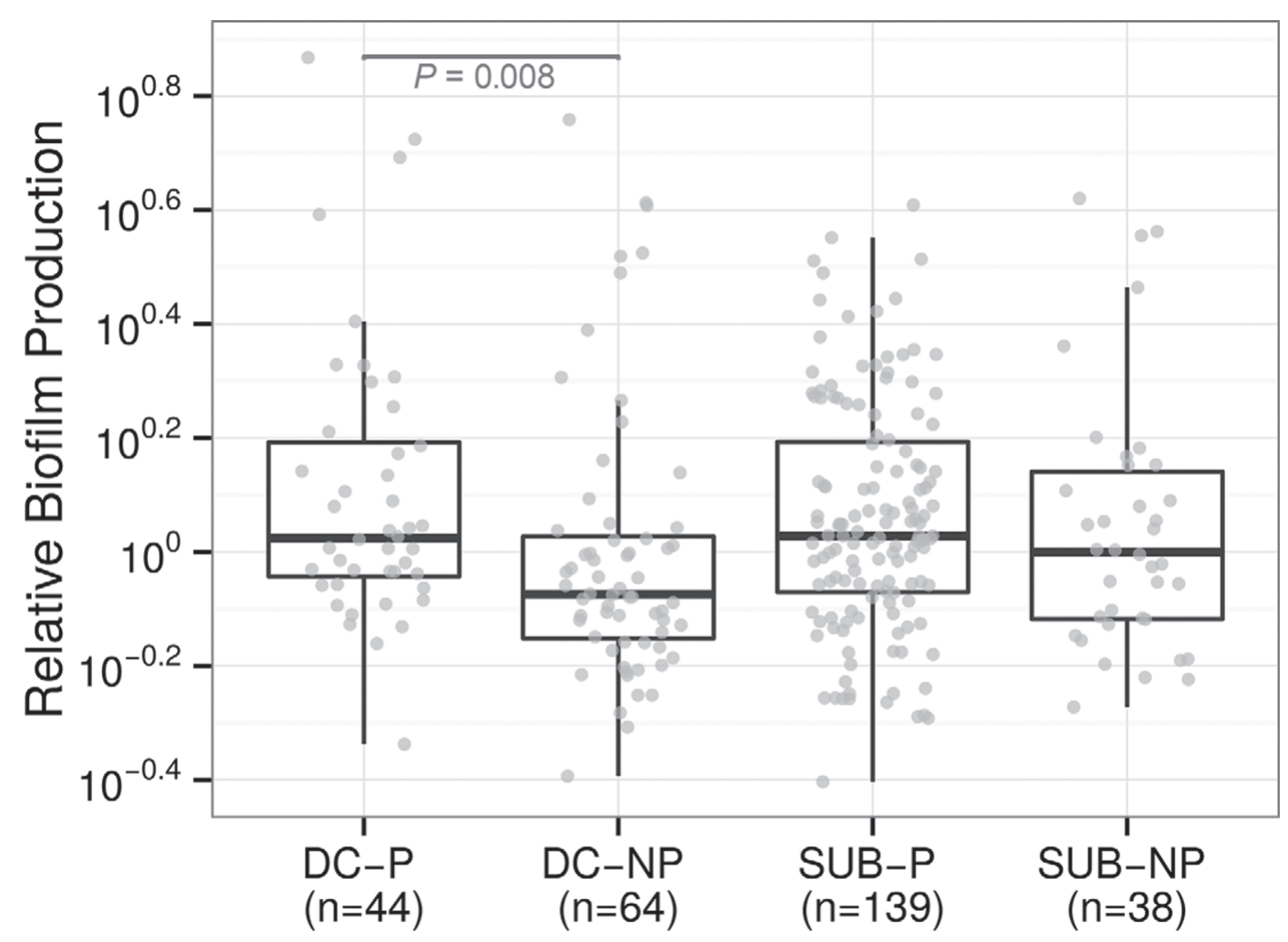

Figure 1. Boxplots of biofilm production in vitro for the different groups of Staphylococcus aureus strains. Each symbol represents one strain. Each IMI case is represented by one strain. The horizontal bars represent the medians. SUB-P = persistent strains from subclinical IMI during lactation; SUB-NP = nonpersistent strains from subclinical IMI during lactation; DC-P = strains from subclinical IMI persisting through the dry period; DC-NP = strains from subclinical IMI not persisting through the dry period (i.e., not found in fresh cows). Only significant $P$-values are indicated.

DC-P and DC-NP strains. However, strains expressing more hld were more likely to be nonpersistent during either lactation or over the dry period (OR: $0.93,95 \%$ $\mathrm{CI}=0.87-1.00, P=0.040$; and $\mathrm{OR}=0.85,95 \% \mathrm{CI}$ : $0.75-0.96, P=0.011$, respectively).

\section{spa Typing}

A total of 18 different spa types were identified from a random selection of 150 strains (out of the 285 total strains studied here) that included 78 and 72 strains from the lactation and dry period, respectively. All had 2 to 13 repeats, and the numeric code of the spa types was assigned based on the repeat succession. Fifteen strains, however, revealed a novel spa type, which is now registered as t13401 after submission to the Ridom Spa database server. The distribution of these 18 spa types among the strain groups is reported in Table 3 . The spa type $\mathrm{t} 529(\mathrm{n}=66)$ was the most common and was present in all groups of strains although it was less frequent in DC-P isolates. The second and third predominant spa types were t267 $(\mathrm{n}=29)$ and the novel type t13401 (n $=15$ ). Figures 3 and 4 show some properties (biofilm production in vitro and hld expression, respectively) of the most frequent spa types $(\mathrm{n} \geq 5)$. Strains of type $\mathrm{t} 529$ produced significantly less biofilm than strains from other spa types such as t605, t1166, or the t13401 ( $P$ $=0.001, P=0.004, P<0.001$, respectively, Figure 3), whereas the novel t13401 spa-type strains produced more biofilm than types t267, t359, and t529 $(P<0.001, P<$ 0.001 , and $P<0.001$, respectively, Figure 3). Inversely, the t529 strains expressed higher hld levels than types t267, t605, t3380, and t13401 $(P=0.019, P<0.001, P$ $<0.001$, and $P<0.001$, respectively, Figure 4). Type t529 strains thus generally produced less biofilm and showed elevated hld expression compared with strains from several other spa types.

Table 4 shows the distribution of the enterotoxin genes studied among strains of the 3 major spa types. Superantigen genes were detected in many t529 strains, and $97.0 \%$ of t529 strains were positive for both sen and seg genes, whereas most of the strains from types t267 (96.6\%) and t13401 (86.7\%) were negative for sen, seg, or both. Table 5 reports the distribution of genes among the different groups of strains belonging to the spa type t529.

Statistical analysis (logistic regression) for t529 strains recovered over the dry period revealed that this 
Table 3. Distribution (\%) of 150 Staphylococcus aureus strains among the different spa types ${ }^{1}$

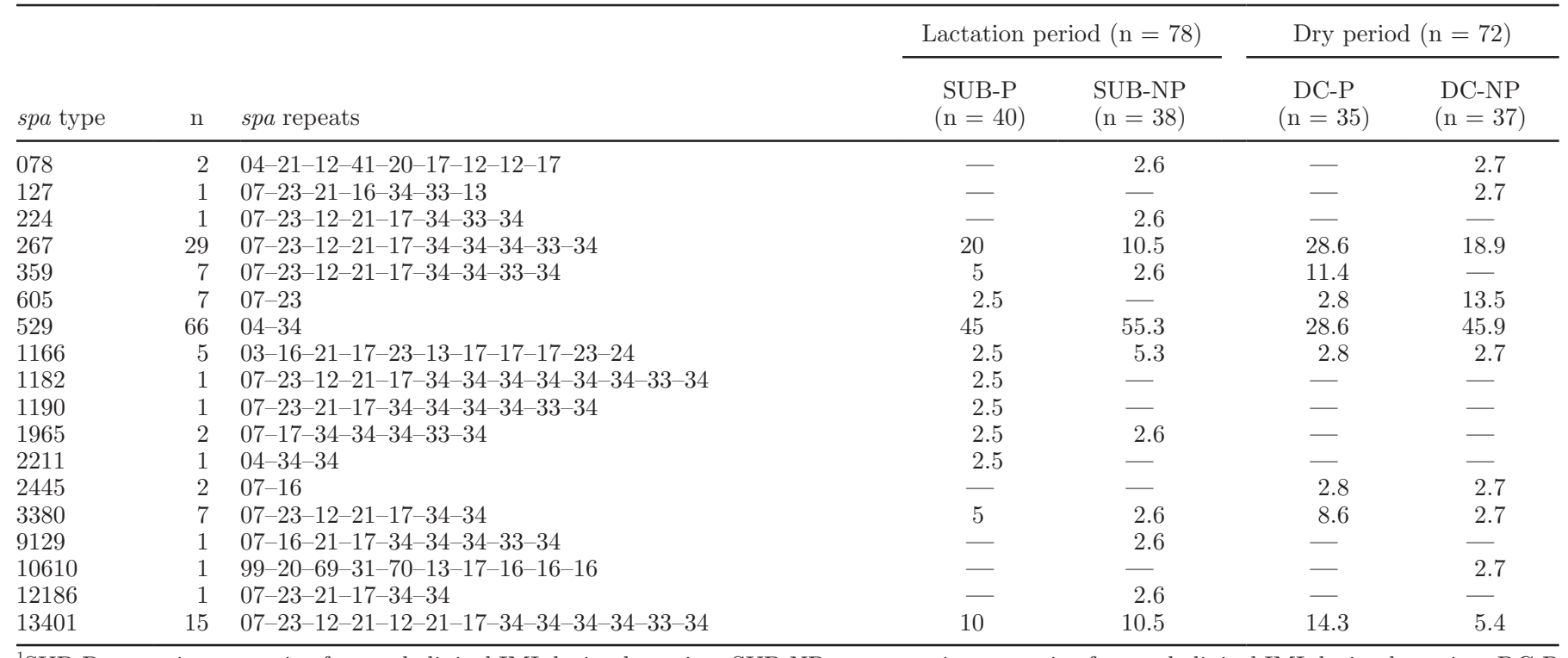

${ }^{1}$ SUB-P $=$ persistent strains from subclinical IMI during lactation; SUB-NP = nonpersistent strains from subclinical IMI during lactation; DC-P $=$ strains from subclinical IMI persisting through the dry period; DC-NP = strains from subclinical IMI not persisting through the dry period (i.e., not found in fresh cows).

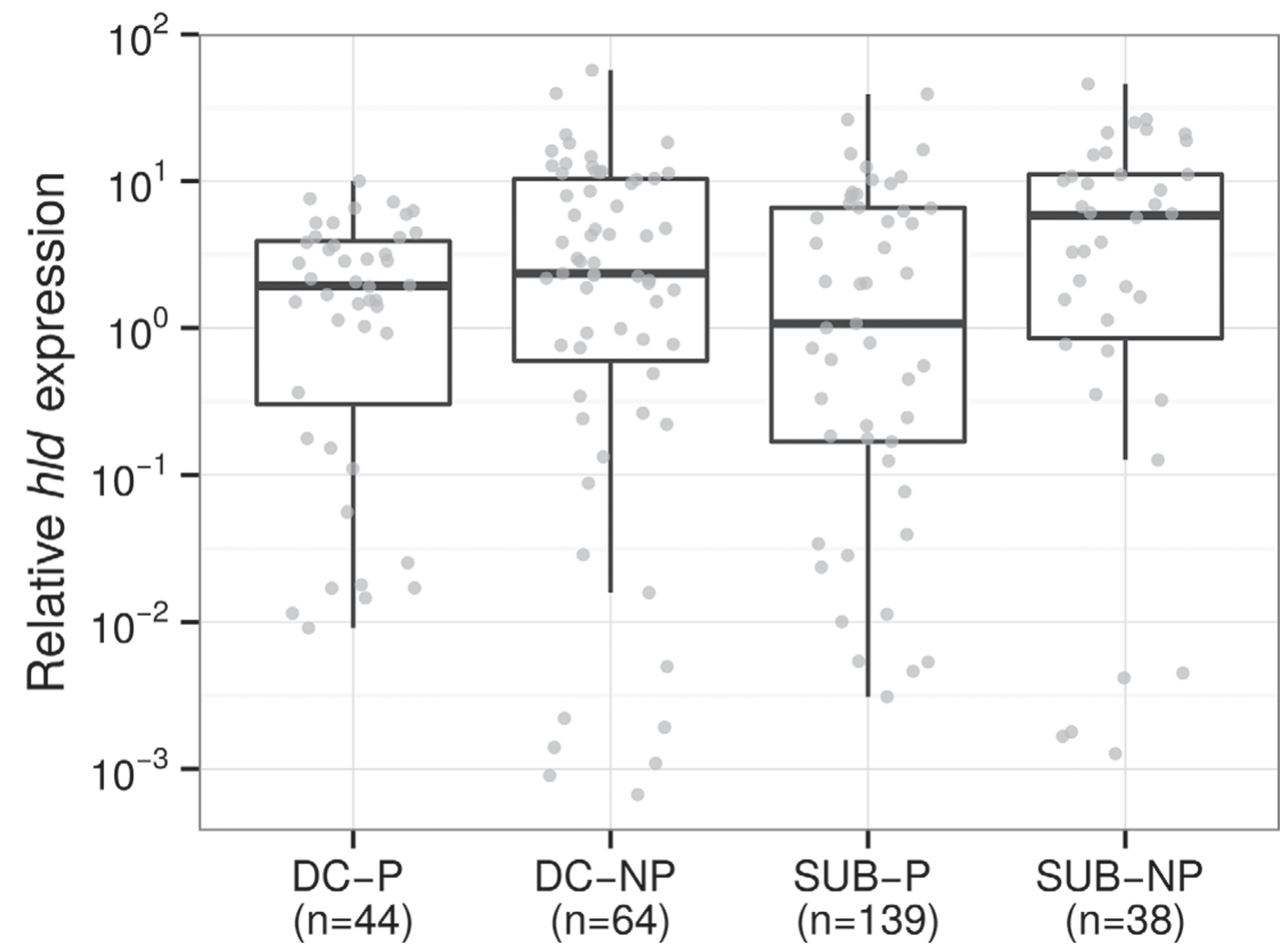

Figure 2. Boxplots of hld expression levels for the different groups of Staphylococcus aureus strains. Each symbol represents one strain. Each IMI case is represented by one strain. The horizontal bars represent the median. SUB-P = persistent strains from subclinical IMI during lactation; SUB-NP = nonpersistent strains from subclinical IMI during lactation; DC-P $=$ strains from subclinical IMI persisting through the dry period; DC-NP = strains from subclinical IMI not persisting through the dry period (i.e., not found in fresh cows). No significant difference was found between groups. 


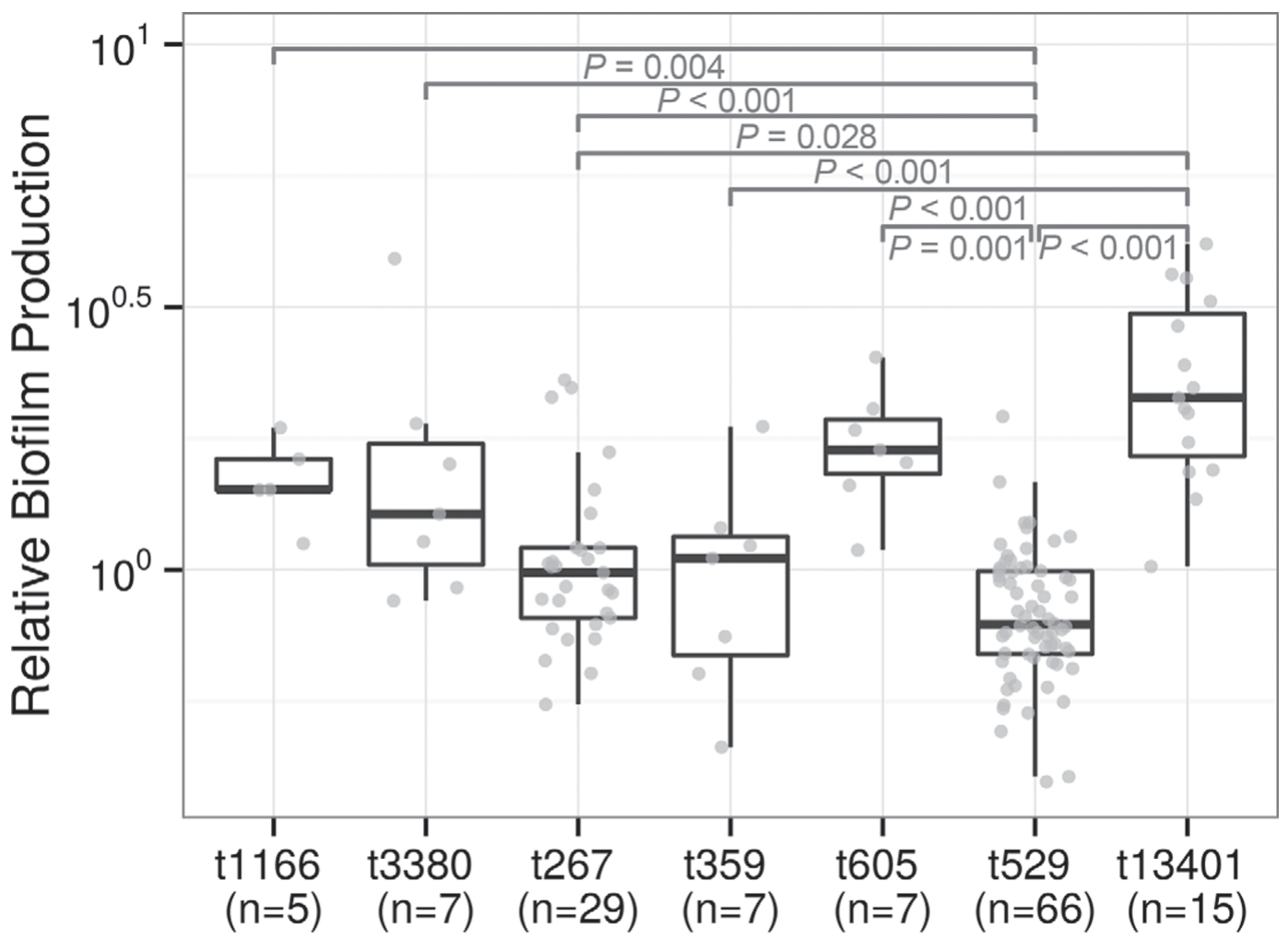

Figure 3. Boxplots of biofilm production in vitro for the predominant spa types of Staphylococcus aureus. Each symbol represents one strain. Each IMI case is represented by one strain. The horizontal bars represent the medians. Only significant $P$-values are indicated.

spa type is associated with a reduction in the possibility that the bacteria persist by $70 \%(\mathrm{OR}=0.30,95 \% \mathrm{CI}$ : $0.10-0.90, P=0.032$ ). Table 3 shows the distribution of strains from the spa type t529 among the persistent and nonpersistent groups.

Simpson diversity index represents 1 - probability that any 2 strains drawn from the strain population are the same and ranges from zero ( $100 \%$ probability) to one ( $0 \%$ probability). Genetic diversity was found to be equivalent in all groups. Simpson indices were $72.9,67.6,79.3$, and $72.8 \%$ for SUB-P, SUB-NP, DC-P, DC-NP, respectively.

\section{DISCUSSION}

Systematic screening of quarter milk samples in the CBMRN National Cohort of Dairy Farms over a 2-yr period generated a bacterial culture collection that contains more than 16,500 isolates, all epidemiologically cross-referenced between linked databases that document bacteriology information, the type of sample (repeated milk samplings from fresh and randomly selected lactating cows, and cows at dry-off and after calving), udder health, demographics, and production data for individual cows and farms (Reyher et al., 2011). This culture collection and databases allowed us to specifi- cally look for isolates of interest, and the principal aim of the present study was to compare persistent and nonpersistent $S$. aureus isolates from subclinical IMI in the hope of identifying bacterial characteristics associated with persistence.

One difficulty in such an investigation is the precision in the definition of cases and whether or not the studied strains can belong to the persistent or nonpersistent group. Our selection criteria for lactational IMI persistence demanded the presence of the same strain 3 consecutive times in the same quarter milk samples over a period of $6 \mathrm{wk}$. Variable number of tandem repeats was used to predict that the 3 isolates recovered from these samplings could indeed represent the same persistent strain. As for the persistent strains recovered over the dry period, the databases allowed identification of $S$. aureus isolates collected before and after the dry period and therefore still present in fresh cows.

We feel that optimal data comparisons can be carried out between SUB-NP and SUB-P strains (nonpersistent and persistent lactational IMI strains, respectively) and between DC-NP and DC-P strains (nonpersistent and persistent IMI isolates recovered over the dry period, respectively). One can anticipate that persistent isolates collected during lactation can be the same as those that persist through the dry period and vice versa despite 
Table 4. Distribution (\%) of target genes among 110 strains of the 3 major spa types

\begin{tabular}{lccc}
\hline & \multicolumn{3}{c}{ spa type } \\
\cline { 2 - 4 } Gene & $\mathrm{t} 529$ & $\mathrm{t} 267$ & $\mathrm{t} 13401$ \\
$(\mathrm{n}=66)$ & $(\mathrm{n}=29)$ & $15)$ \\
\hline sec+ & 12.1 & 3.4 & 0 \\
tst+ & 15.1 & 10.3 & 20.0 \\
seg+ & 97.0 & 13.8 & 13.3 \\
sen+ & 98.5 & 17.2 & 40.0 \\
sen+ and seg+ & 97.0 & 3.4 & 13.3 \\
sen-, seg-, or both & 3.0 & 96.6 & 86.7 \\
\hline
\end{tabular}

the changing physiology of the mammary gland. Comparison of these 2 groups of strains would, however, be difficult because all dry cows were submitted to antibiotherapy and implies that $S$. aureus strains that persisted through freshening were under an additional selective pressure. Still, antibiotic susceptibility testing done on many dry-cow strains showed equivalent susceptibility levels between DC-P and DC-NP strains, and it is unlikely that in vitro antibiotic resistance per se is primarily responsible for the persistence of the studied DC-P strains (F. Malouin, unpublished data).

This study thus used persistent and nonpersistent isolates collected from cows with subclinical IMI during lactation or the dry period. These isolates were investi- gated for the presence of superantigen genes (sen, sec, seg, and tst), biofilm production in vitro, hld-RNAIII expression level, and spa type to obtain valuable information on genotypic and phenotypic patterns that could be used to predict $S$. aureus persistence.

The diversity of genotypic and phenotypic observations on $S$. aureus strains obtained from bovine IMI have previously been reported by multiple studies. Investigations that more specifically characterized distinct groups of strains such as those causing persistent bovine mastitis are also available but scarce (Haveri et al., 2005, 2007; Piccinini et al., 2012). These latter studies used a variety of methods of analysis for strains characterization (e.g., pulsed-field gel electrophoresis

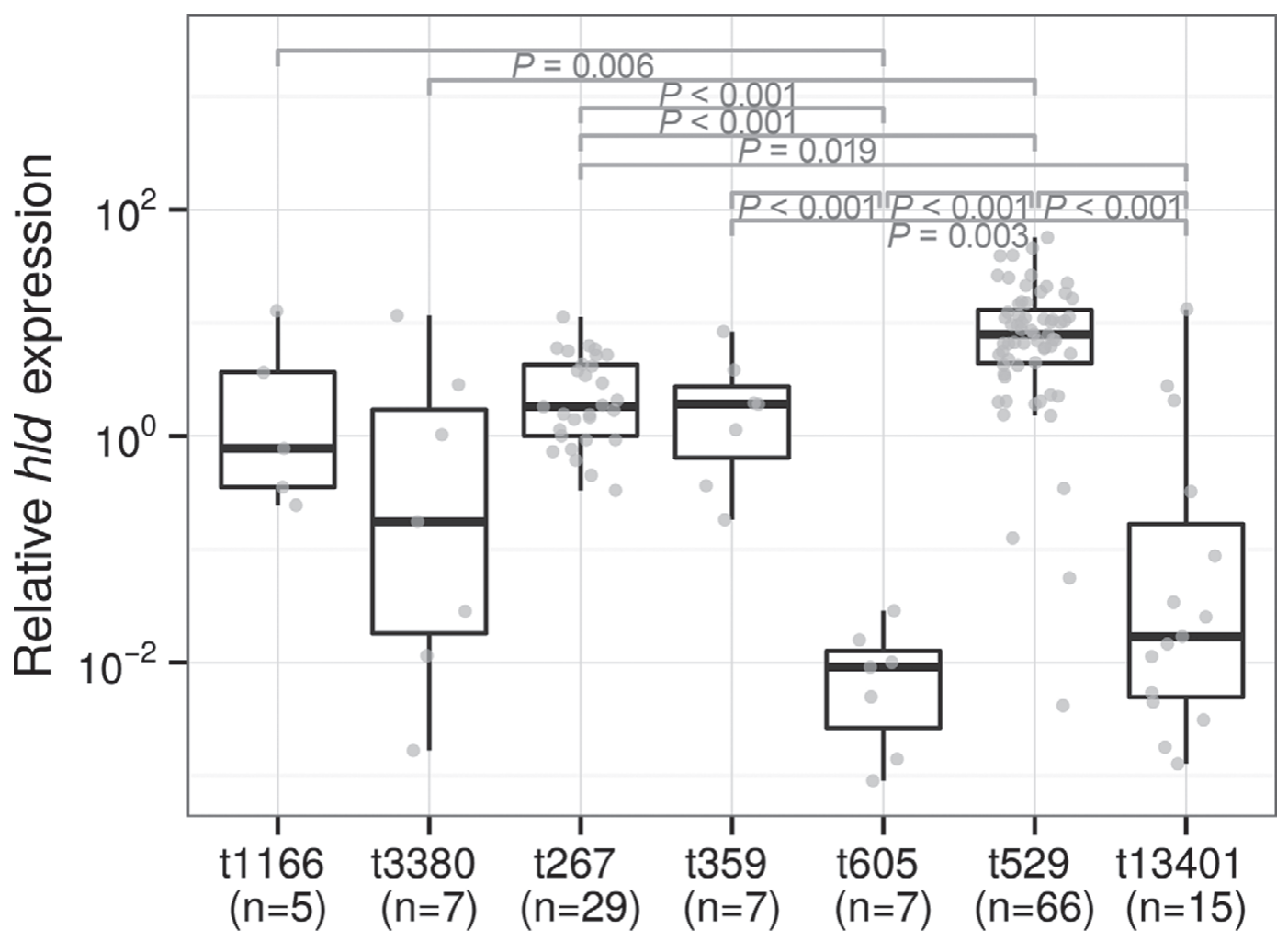

Figure 4. Boxplots of hld expression levels for the predominant spa types of Staphylococcus aureus. Each symbol represents one strain. Each IMI case is represented by one strain. The horizontal bars represent the medians. Only significant $P$-values are indicated. 
Table 5. Distribution (\%) of target genes among 66 strains of the major spa type t5291

\begin{tabular}{lccccc}
\hline & \multicolumn{2}{c}{ Lactation period $(\mathrm{n}=39)$} & & \multicolumn{2}{c}{ Dry period $(\mathrm{n}=27)$} \\
\cline { 2 - 3 } \cline { 5 - 6 } Gene & $\begin{array}{c}\text { SUB-P } \\
(\mathrm{n}=19)\end{array}$ & $\begin{array}{c}\text { SUB-NP } \\
(\mathrm{n}=20)\end{array}$ & & $\begin{array}{c}\text { DC-P } \\
(\mathrm{n}=10)\end{array}$ & $\begin{array}{c}\text { DC-NP } \\
(\mathrm{n}=17)\end{array}$ \\
\hline sec+ & 5.2 & 20 & & 20 & 5.9 \\
tst+ & 5.2 & 25 & & 20 & 11.8 \\
seg+ & 100 & 100 & & 100 & 88.2 \\
sen+ & 100 & 100 & & 100 & 94.1 \\
sen+ and seg+ & 100 & 100 & & 100 & 88.2 \\
sen-, seg-, or both & 0 & 0 & & 0 & 11.8 \\
\hline
\end{tabular}

${ }^{1}$ SUB-P $=$ persistent strains from subclinical IMI during lactation; SUB-NP = nonpersistent strains from subclinical IMI during lactation; DC-P = strains from subclinical IMI persisting through the dry period; DC-NP $=$ strains from subclinical IMI not persisting through the dry period (i.e., not found in fresh cows).

pulsotypes, multilocus sequence typing, PCR, microarray analysis), various groups of strains (subclinical, clinical), and various definitions or estimation of persistence, for example, persistence after antibiotic therapy or follow-up examination 4 wk after the initial detection of IMI or cows showing a chronic mastitis but without evidence that the disease was due to a single strain or a succession of new infections. This variation in methods and estimation and definition of persistence makes it very difficult to carry out comparisons across studies and between different types of infections. Here, because of the large collection of $S$. aureus strains we had in hand, we were able to specifically select strains from subclinical IMI and had a strong presumption of the ability of the strains to cause persistent or nonpersistent IMI.

For this investigation we restricted the set of superantigen genes we have examined to sen, sec, seg, and tst because in our hands these genes were the most discriminatory in a preliminary microarray hybridization study evaluating mastitis strain diversity (Jacob et al., 2008). In the present study, results suggest that the presence of seg reduces the odds for a strain found in a subclinical IMI during lactation to be persistent. Haveri et al. (2007) similarly showed that strains possessing seg, sen, sec or tst were less likely to persist, although this persistence was defined as a detection of $S$. aureus after therapy for IMI occurring during lactation. In our study, although strains from the spa types t267 and t13401 can be negative for seg or sen, strains from the spa type t529 were most often positive for both of these genes and were less likely to cause a persistent IMI in the dry period. Such coexistence of seg and sen in the same isolates has been reported. This phenomenon is attributed to their being often in the same enterotoxin gene cluster $(e g c)$, located on the genomic island $\mathrm{vSa} \beta$ (Wang et al., 2009; Malachowa and DeLeo, 2010; Ote et al., 2011; Wolf et al., 2011; Piccinini et al., 2012). In addition, sec and tst genes or their combined presence suggested that some of the strains contained the patho- genicity island SaPIbov (Fitzgerald et al., 2001; Wang et al., 2009; Ote et al., 2011; Wolf et al., 2011). Thus, the superantigen genes tested in our study (seg, sen, $s e c$, and $t s t$ ) can be located on 2 pathogenicity islands (SaPIbov and $\nu \mathrm{Sa} \beta$ ), which could appear either alone or together in the same isolate. Some strains, however, for example from the spa types t267 and t13401, show that the presence of seg or sen and of sec or tst can also occur alone as seen in other studies (Zschöck et al., 2005; Haveri et al., 2007; Wang et al., 2009; Mitra et al., 2013).

Based on in vitro work performed with IMI isolates, biofilm production was shown to correlate with intracellular survival in mammary epithelial cell cultures (Bardiau et al., 2014) and has been proposed to decrease the susceptibility of $S$. aureus to antimicrobial agents (Cucarella et al., 2004; Melchior et al., 2006; Melchior et al., 2007). Here we elected to measure biofilm production in vitro by using a 96-well plate colorimetric procedure because this technique was highly reproducible in our hands, especially with the inclusion of a reference strain for the normalization of data in each assay. The present study showed that persistent DC-P strains from the dry period produced significantly more biofilm in vitro than strains that do not persist in fresh cows (DC-NP). As seen in vitro with the reduction of antibiotic activity against bacteria imbedded in biofilms, it is possible that blanket therapy during the dry period is less efficient against $S$. aureus strains showing high biofilm production, although no in vivo study can yet directly support such a hypothesis. Also, as evaluated here, increase in biofilm production did not significantly increase the odds of being persistent in the strain populations we studied.

The production of exotoxins (e.g., hemolysins) and biofilm disruptive molecules (nucleases, proteases, phenol-soluble modulins) following the activation of the Agr quorum-sensing system and expression of $h l d-$ RNAIII is now well accepted (Novick and Geisinger, 2008; Otto, 2013). In our study, strains expressing more 
$h l d$ were more likely to be nonpersistent during either lactation or the dry period based on the calculation of the odd ratios. Also, for strains of some of the spa types, notably t13401, high biofilm production was seen accompanied with low hld expression and vice versa for strains of the spa type t529. This inverse relationship is in agreement with the current understanding of biofilm maturation and disruption (Otto, 2013).

The spa gene mediates host-pathogen interactions, and the sequence repeats of its polymorphic region can be used for typing $S$. aureus isolates (Said et al., 2010). The spa gene has been indeed one of the most successful single genetic markers used for the typing of S. aureus strains (Aires-de-Sousa et al., 2006). In the present study, the analysis of $150 \mathrm{~S}$. aureus strains by spa typing revealed 18 different spa types, of which t529 and t267 were found in the majority of isolates. A high prevalence of t267 in subclinical mastitis strains from India was reported (Mitra et al., 2013). Our results are in general agreement with those of Said et al. (2010), who have observed a predominance of spa type t529 and t267 in strains from clinical mastitis in Canada. It should be noted that we also revealed the presence of a significant number of strains with a novel spa type (t13401). This novel spa type was poorly represented in strains causing clinical mastitis ( 1 out of 45 ; F. Malouin, unpublished data) and may explain their absence in the study of Said et al. (2010). Strains from t13401 produced significantly more biofilm and showed lower Agr activation than that seen with the t529 isolates.

$S$. aureus IMI strains that persist during lactation and those strains that persist from dry-off to freshening are especially problematic because they provide a reservoir for new infections within the herd. Identification of efficient markers that distinguished between those $S$. aureus more likely to persist and those less likely to persist will help udder-health-management decision making. For such a purpose, additional analyses and mechanistic studies will be required to prove the role and further associate with persistent IMI in the field some of the overrepresented bacterial genetic traits and in vitro characteristics we noticed in this study. Also to consider in future studies is the effective duration of IMI in addition to persistence, which here was defined as of at least $6 \mathrm{wk}$ without, however, any knowledge of IMI status before day zero. Additional studies may need to also consider the contribution of bovine host genetic and immune status because these factors should also greatly influence bacterial persistence in the mammary gland.

\section{ACKNOWLEDGMENTS}

This research was supported by a contribution from the Dairy Research Cluster initiative [Dairy Farmers of
Canada (Ottawa, ON, Canada), Agriculture and AgriFood Canada (Ottawa, ON, Canada), and the Canadian Dairy Commission (Ottawa, ON, Canada)] through the Canadian Bovine Mastitis and Milk Quality Research Network (St-Hyacinthe, QC, Canada). The Canadian Bovine Mastitis and Milk Quality Research Network is supported by the Natural Sciences and Engineering Research Council (NSERC) of Canada; Alberta Milk; Dairy Farmers of New Brunswick, Nova Scotia, Ontario, and Prince Edward Island; Novalait Inc.; Dairy Farmers of Canada; Canadian Dairy Network; AAFC; PHAC; Technology PEI Inc.; Université de Montréal; and University of Prince Edward Island. This work was also supported by Discovery grant 89758-2010 from NSERC to F. M. R. C. K. was supported by a PhD scholarship from CAPES-Brazil. Finally, we thank Eric Frost and Sophie Michaud for access to the Bionumerics software and databases.

\section{REFERENCES}

Aires-de-Sousa, M., K. Boye, H. de Lencastre, A. Deplano, M. C. Enright, J. Etienne, A. Friedrich, D. Harmsen, A. Holmes, X. W. Huijsdens, A. M. Kearns, A. Mellmann, H. Meugnier, J. K. Rasheed, E. Spalburg, B. Strommenger, M. J. Struelens, F. C. Tenover, J. Thomas, U. Vogel, H. Westh, J. Xu, and W. Witte. 2006. High interlaboratory reproducibility of DNA sequence-based typing of bacteria in a multicenter study. J. Clin. Microbiol. 44:619-621.

Akineden, O., C. Annemüller, A. A. Hassan, C. Lämmler, W. Wolter, and M. Zschöck. 2001. Toxin genes and other characteristics of Staphylococcus aureus isolates from milk of cows with mastitis. Clin. Diagn. Lab. Immunol. 8:959-964.

Bardiau, M., J. Detilleux, F. Farnir, J. G. Mainil, and I. Ote. 2014. Associations between properties linked with persistence in a collection of Staphylococcus aureus isolates from bovine mastitis. Vet. Microbiol. 169:74-79.

Buzzola, F. R., L. Quelle, M. I. Gomez, M. Catalano, L. Steele-Moore, D. Berg, E. Gentilini, G. Denamiel, and D. O. Sordelli. 2001. Genotypic analysis of Staphylococcus aureus from milk of dairy cows with mastitis in Argentina. Epidemiol. Infect. 126:445-452.

Costerton, J. W., P. S. Stewart, and E. P. Greenberg. 1999. Bacterial biofilms: A common cause of persistent infections. Science $284: 1318-1322$.

Cucarella, C., M. A. Tormo, C. Ubeda, M. P. Trotonda, M. Monzón, C. Peris, B. Amorena, I. Lasa, and J. R. Penadés. 2004. Role of biofilm-associated protein bap in the pathogenesis of bovine Staphylococcus aureus. Infect. Immun. 72:2177-2185.

Davies, D. 2003. Understanding biofilm resistance to antibacterial agents. Nat. Rev. Drug Discov. 2:114-122.

Dhanawade, N. B., D. R. Kalorey, R. Srinivasan, S. B. Barbuddhe, and N. V. Kurkure. 2010. Detection of intercellular adhesion genes and biofilm production in Staphylococcus aureus isolated from bovine subclinical mastitis. Vet. Res. Commun. 34:81-89.

Dinges, M. M., P. M. Orwin, and P. M. Schlievert. 2000. Exotoxins of Staphylococcus aureus. Clin. Microbiol. Rev. 13:16-34.

Dixon, P. M. 1993. The bootstrap and the jacknife: Describing the precision of ecological indices. Pages 267-288 in Design and Analysis of Ecological Experiments. S. M. Scheiner and J. Gurevitch, ed. Chapman Hall, New York, NY.

Dohoo, I. R., J. Smith, S. Andersen, D. F. Kelton, S. Godden, and Mastitis Research Workers' Conference. 2011. Diagnosing intramammary infections: Evaluation of definitions based on a single milk sample. J. Dairy Sci. 94:250-261.

Efron, B., and R. Tibshirani. 1997. Improvements on cross-validation: The bootstrap method. J. Am. Stat. Assoc. 92:548-560. 
Fitzgerald, J. R., P. J. Hartigan, W. J. Meaney, and C. J. Smyth. 2000. Molecular population and virulence factor analysis of Staphylococcus aureus from bovine intramammary infection. J. Appl. Microbiol. 88:1028-1037.

Fitzgerald, J. R., S. R. Monday, T. J. Foster, G. A. Bohach, P. J. Hartigan, W. J. Meaney, and C. J. Smyth. 2001. Characterization of a putative pathogenicity island from bovine Staphylococcus aureus encoding multiple superantigens. J. Bacteriol. 183:63-70.

Hata, E., K. Katsuda, H. Kobayashi, I. Uchida, K. Tanaka, and M. Eguchi. 2010. Genetic variation among Staphylococcus aureus strains from bovine milk and their relevance to methicillin-resistant isolates from humans. J. Clin. Microbiol. 48:2130-2139.

Haveri, M., M. Hovinen, A. Roslöf, and S. Pyörälä. 2008. Molecular types and genetic profiles of Staphylococcus aureus strains isolated from bovine intramammary infections and extramammary sites. J. Clin. Microbiol. 46:3728-3735.

Haveri, M., A. Roslöf, L. Rantala, and S. Pyörälä. 2007. Virulence genes of bovine Staphylococcus aureus from persistent and nonpersistent intramammary infections with different clinical characteristics. J. Appl. Microbiol. 103:993-1000.

Haveri, M., S. Taponen, J. Vuopio-Varkila, S. Salmenlinna, and S. Pyörälä. 2005. Bacterial genotype affects the manifestation and persistence of bovine Staphylococcus aureus intramammary infection. J. Clin. Microbiol. 43:959-961.

Jacob, C. L., B. Lefebvre, E. Poirier, J.-P. Roy, D. Scholl, and F. Malouin. 2008. Comparative genomics and virulence potential of Staphylococcus aureus isolates from chronic mastitis. 108th Ann. Mtg. Am. Soc. Microbiol., Boston, MA.

Jarraud, S., C. Mougel, J. Thioulouse, G. Lina, H. Meugnier, F. Forey, X. Nesme, J. Etienne, and F. Vandenesch. 2002. Relationships between Staphylococcus aureus genetic background, virulence factors, agr groups (alleles), and human disease. Infect. Immun. 70:631-641.

Kalorey, D. R., Y. Shanmugam, N. V. Kurkure, K. K. Chousalkar, and S. B. Barbuddhe. 2007. PCR-based detection of genes encoding virulence determinants in Staphylococcus aureus from bovine subclinical mastitis cases. J. Vet. Sci. 8:151-154.

Klein, R. C., M. H. Fabres-Klein, M. A. Brito, L. G. Fietto, and O. Ribon Ade. 2012. Staphylococcus aureus of bovine origin: Genetic diversity, prevalence and the expression of adhesin-encoding genes. Vet. Microbiol. 160:183-188.

Larsen, H. D., F. M. Aarestrup, and N. E. Jensen. 2002. Geographical variation in the presence of genes encoding superantigenic exotoxins and beta-hemolysin among Staphylococcus aureus isolated from bovine mastitis in Europe and USA. Vet. Microbiol. 85:61-67.

Le Maréchal, C., N. Seyffert, J. Jardin, D. Hernandez, G. Jan, L. Rault, V. Azevedo, P. François, J. Schrenzel, M. van de Guchte, S. Even, N. Berkova, R. Thiéry, J. R. Fitzgerald, E. Vautor, and Y. Le Loir. 2011. Molecular basis of virulence in Staphylococcus aureus mastitis. PLoS ONE 6:e27354.

Malachowa, N., and F. R. DeLeo. 2010. Mobile genetic elements of Staphylococcus aureus. Cell. Mol. Life Sci. 67:3057-3071.

Matsunaga, T., S. Kamata, N. Kakiichi, and K. Uchida. 1993. Characteristics of Staphylococcus aureus isolated from peracute, acute and chronic bovine mastitis. J. Vet. Med. Sci. 55:297-300.

Mehrotra, M., G. Wang, and W. M. Johnson. 2000. Multiplex PCR for detection of genes for Staphylococcus aureus enterotoxins, exfoliative toxins, toxic shock syndrome toxin 1 , and methicillin resistance. J. Clin. Microbiol. 38:1032-1035.

Melchior, M. B., J. Fink-Gremmels, and W. Gaastra. 2007. Extended antimicrobial susceptibility assay for Staphylococcus aureus isolates from bovine mastitis growing in biofilms. Vet. Microbiol. 125:141-149.

Melchior, M. B., H. Vaarkamp, and J. Fink-Gremmels. 2006. Biofilms: A role in recurrent mastitis infections? Vet. J. 171:398-407.

Mills, J. A., and A. Zandvakili. 1997. Statistical inference via bootstrapping for measures of inequality. J. Appl. Econ. 12:133-150.

Mitchell, G., C.-A. Lamontagne, E. Brouillette, G. Grondin, B. G. Talbot, M. Grandbois, and F. Malouin. 2008. Staphylococcus aureus $\mathrm{SigB}$ activity promotes a strong fibronectin-bacterium interaction which may sustain host tissue colonization by small-colony variants isolated from cystic fibrosis patients. Mol. Microbiol. 70:1540-1555.

Mitchell, G., D. L. Séguin, A.-E. Asselin, E. Déziel, A. M. Cantin, E. H. Frost, S. Michaud, and F. Malouin. 2010. Staphylococcus aureus sigma B-dependent emergence of small-colony variants and biofilm production following exposure to Pseudomonas aeruginosa 4-hydroxy-2-heptylquinoline-N-oxide. BMC Microbiol. 10:33-47.

Mitra, S. D., D. Velu, M. Bhuvana, N. Krithiga, A. Banerjee, R Shome, H. Rahman, S. K. Ghosh, and B. R. Shome. 2013. Staphylococcus aureus spa type t267, clonal ancestor of bovine subclinical mastitis in India. J. Appl. Microbiol. 114:1604-1615.

Moisan, H., E. Brouillette, C. L. Jacob, P. Langlois-Bégin, S. Michaud, and F. Malouin. 2006. Transcription of virulence factors in Staphylococcus aureus small-colony variants isolated from cystic fibrosis patients is influenced by SigB. J. Bacteriol. 188:64-76.

Novick, R. P. 2003. Autoinduction and signal transduction in the regulation of staphylococcal virulence. Mol. Microbiol. 48:1429-1449.

Novick, R. P., and E. Geisinger. 2008. Quorum sensing in staphylococci. Annu. Rev. Genet. 42:541-564.

Olde Riekerink, R. G., H. W. Barkema, D. F. Kelton, and D. T. Scholl. 2008. Incidence rate of clinical mastitis on Canadian dairy farms. J. Dairy Sci. 91:1366-1377.

Oliveira, L., A. C. Rodrigues, C. Hulland, and P. L. Ruegg. 2011. Enterotoxin production, enterotoxin gene distribution, and genetic diversity of Staphylococcus aureus recovered from milk of cows with subclinical mastitis. Am. J. Vet. Res. 72:1361-1368.

Oliveira, M., R. Bexiga, S. F. Nunes, C. Carneiro, L. M. Cavaco, F. Bernardo, and C. L. Vilela. 2006. Biofilm-forming ability profiling of Staphylococcus aureus and Staphylococcus epidermidis mastitis isolates. Vet. Microbiol. 118:133-140.

Ote, I., B. Taminiau, J.-N. Duprez, I. Dizier, and J. G. Mainil. 2011. Genotypic characterization by polymerase chain reaction of Staphylococcus aureus isolates associated with bovine mastitis. Vet. Microbiol. 153:285-292.

Otto, M. 2013. Staphylococcal infections: Mechanisms of biofilm maturation and detachment as critical determinants of pathogenicity. Annu. Rev. Med. 64:175-188.

Periasamy, S., H.-S. Joo, A. C. Duong, T.-H. L. Bach, V. Y. Tan, S. S. Chatterjee, G. Y. C. Cheung, and M. Otto. 2012. How Staphylococcus aureus biofilms develop their characteristic structure. Proc. Natl. Acad. Sci. USA 109:1281-1286.

Piccinini, R., R. Tassi, V. Daprà, R. Pilla, J. Fenner, B. Carter, and M. F. Anjum. 2012. Study of Staphylococcus aureus collected at slaughter from dairy cows with chronic mastitis. J. Dairy Res. $79: 249-255$.

R Core Team. 2012. R: A Language and Environment for Statistical Computing. R Found. Stat. Comput., Vienna, Austria.

Reyher, K. K., S. Dufour, H. W. Barkema, L. Des Côteaux, T. J. Devries, I. R. Dohoo, G. P. Keefe, J.-P. Roy, and D. T. Scholl. 2011. The National Cohort of Dairy Farms - A data collection platform for mastitis research in Canada. J. Dairy Sci. 94:16161626.

Sabat, A., J. Krzyszton-russjan, W. Strzalka, R. Filipek, K. Kosowska, W. Hryniewicz, J. Travis, and J. Potempa. 2003. New method for typing Staphylococcus aureus strains: Multiple-locus variablenumber tandem repeat analysis of polymorphism and genetic relationships of clinical isolates. J. Clin. Microbiol. 41:1801-1804.

Said, K. B., J. Ismail, J. Campbell, M. R. Mulvey, A.-M. Bourgault, S. Messier, and X. Zhao. 2010. Regional profiling for determination of genotype diversity of mastitis-specific Staphylococcus aureus lineage in Canada by use of clumping factor A, pulsed-field gel electrophoresis, and spa typing. J. Clin. Microbiol. 48:375-386.

Simpson, E. H. 1949. Measurement of diversity. Nature 163:688.

Ster, C., F. B. Gilbert, T. Cochard, and B. Poutrel. 2005. Transcriptional profiles of regulatory and virulence factors of Staphylococcus aureus of bovine origin: Oxygen impact and strain-to-strain variations. Mol. Cell. Probes 19:227-235.

Sutra, L., and B. Poutrel. 1994. Virulence factors involved in the pathogenesis of bovine intramammary infections due to Staphylococcus aureus. J. Med. Microbiol. 40:79-89. 
van Leeuwen, W. B., D. C. Melles, A. Alaidan, M. Al-Ahdal, H. A. M. Boelens, S. V. Snijders, H. Wertheim, E. van Duijkeren, J. K. Peeters, P. J. van der Spek, R. Gorkink, G. Simons, H. A. Verbrugh, and A. van Belkum. 2005. Host- and tissue-specific pathogenic traits of Staphylococcus aureus. J. Bacteriol. 187:4584-4591.

Vautor, E., V. Magnone, G. Rios, K. Le Brigand, D. Bergonier, G. Lina, H. Meugnier, P. Barbry, R. Thiéry, and M. Pépin. 2009. Genetic differences among Staphylococcus aureus isolates from dairy ruminant species: A single-dye DNA microarray approach. Vet. Microbiol. 133:105-114.

Wang, S.-C., C.-M. Wu, S.-C. Xia, Y.-H. Qi, L.-N. Xia, and J.-Z. Shen. 2009. Distribution of superantigenic toxin genes in Staphylococcus aureus isolates from milk samples of bovine subclinical mastitis cases in two major diary production regions of China. Vet. Microbiol. 137:276-281.

Wolf, C., H. Kusch, S. Monecke, D. Albrecht, S. Holtfreter, C. von Eiff, W. Petzl, P. Rainard, B. M. Bröker, and S. Engelmann. 2011.
Genomic and proteomic characterization of Staphylococcus aureus mastitis isolates of bovine origin. Proteomics 11:2491-2502.

Zadoks, R. N., W. B. van Leeuwen, D. Kreft, L. K. Fox, H. W. Barkema, Y. H. Schukken, and A. van Belkum. 2002. Comparison of Staphylococcus aureus isolates from bovine and human skin, milking equipment, and bovine milk by phage typing, pulsed-field gel electrophoresis, and binary typing. J. Clin. Microbiol. 40:38943902.

Zecconi, A., L. Cesaris, E. Liandris, V. Dapra, and R. Piccinini. 2006 Role of several Staphylococcus aureus virulence factors on the inflammatory response in bovine mammary gland. Microb. Pathog. 40:177-183.

Zschöck, M., B. Kloppert, W. Wolter, H. P. Hamann, and C. Lämmler. 2005. Pattern of enterotoxin genes seg, seh, sei and sej positive Staphylococcus aureus isolated from bovine mastitis. Vet. Microbiol. 108:243-249. 